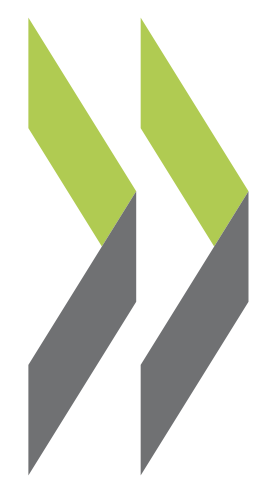

OECD Economics Department Working Papers No. 1451

Making the business environment more supportive of productivity in Belgium

\section{Peter Walkenhorst, \\ Lilas Demmou,} Manav Frohde 
Organisation de Coopération et de Développement Économiques

Organisation for Economic Co-operation and Development

12-Dec-2017

ECONOMICS DEPARTMENT

English - Or. English

\section{MAKING THE BUSINESS ENVIRONMENT MORE SUPPORTIVE OF PRODUCTIVITY IN BELGIUM}

ECONOMICS DEPARTMENT WORKING PAPERS No. 1451

By Peter Walkenhorst, Lilas Demmou and Manav Frohde

OECD Working Papers should not be reported as representing the official views of the OECD or of its member countries. The opinions expressed and arguments employed are those of the author(s).

Authorised for publication by Alvaro Pereira, Director, Country Studies Branch, Economics Department.

All Economics Department Working Papers are available at www.oecd.org/eco/workingpapers.

JT03424625

This document, as well as any data and map included herein, are without prejudice to the status of or sovereignty over any territory, to the delimitation of international frontiers and boundaries and to the name of any territory, city or area. 
OECD Working Papers should not be reported as representing the official views of the OECD or of its member countries. The opinions expressed and arguments employed are those of the author(s).

Working Papers describe preliminary results or research in progress by the author(s) and are published to stimulate discussion on a broad range of issues on which the OECD works.

Comments on Working Papers are welcomed, and may be sent to the Economics Department, OECD, 2 rue André-Pascal, 75775 Paris Cedex 16, France.

All Economics Department Working Papers are available at www.oecd.org/eco/workingpapers.

This document and any map included herein are without prejudice to the status of or sovereignty over any territory, to the delimitation of international frontiers and boundaries and to the name of any territory, city or area.

The statistical data for Israel are supplied by and under the responsibility of the relevant Israeli authorities. The use of such data by the OECD is without prejudice to the status of the Golan Heights, East Jerusalem and Israeli settlements in the West Bank under the terms of international law.

\section{(C) OECD (2017)}

You can copy, download or print OECD content for your own use, and you can include excerpts from OECD publications, databases and multimedia products in your own documents, presentations, blogs, websites and teaching materials, provided that suitable acknowledgment of OECD as source and copyright owner is given. All requests for commercial use and translation rights should be submitted to rights@oecd.org 


\section{ABSTRACT/RESUMÉ \\ Making the business environment more supportive of productivity in Belgium}

A favourable business environment is crucial to boosting Belgium's productivity and inclusiveness and to sustain improvements in long-term economic prosperity. This paper assesses the impact of the business environment on productivity performance. Innovation management, technological diffusion, private and public sector investment, and regulatory and competition policies all affect productivity growth. Key challenges for Belgium include improving the effectiveness of existing tax exemptions for R\&D activities, addressing regulatory burdens on firms, improving access to finance for young innovative firms and fostering an entrepreneurial start-up culture.

This Working Paper relates to the 2017 OECD Economic Survey of Belgium (www.oecd.org/eco/surveys/economic-survey-belgium.htm).

JEL Classification: O31, O32, O43, R4, L5

Keywords: Belgium, productivity, innovation, technological diffusion, infrastructure, firm dynamism, entrepreneurship, regulation in services

$* * * * * * * * * *$

\section{Rendre l'environnement économique plus propice aux gains de productivité en Belgique}

Un environnement économique favorable est crucial pour stimuler la productivité en Belgique et l'inclusivité, et est le principal moteur de la prospérité économique à long terme. Ce document analyse l'impact de l'environnement économique sur la performance de productivité. La gestion des innovations, la diffusion technologique, l'investissement des secteurs privé et public ainsi que les politiques de concurrence et de régulation ont tous un impact sur la croissance de la productivité. Les défis clefs pour la Belgique incluent la modulation des exonérations fiscales en vigueur en faveur des activités de recherchedéveloppement afin d'améliorer leur utilisation et leur efficacité ; la réduction des charges administratives sur les entreprises, l'amélioration de l'accès à la finance pour les jeunes entreprises innovantes et la stimulation de la culture entrepreneuriale en matière de jeunes pousses.

Ce Document de travail se rapporte à l'Etude économique de l'OCDE de la Belgique 2017 (www.oecd.org/fr/eco/etudes/etude-economique-Belgique.htm).

Classification JEL: O31, O32, O43, R4, L5

Mots-clés :Belgique, productivité, innovation, diffusion technologique, infrastructures, dynamisme des firms, culture d'entreprise, régulation du secteur des services 


\section{TABLE OF CONTENTS}

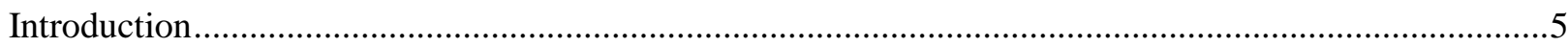

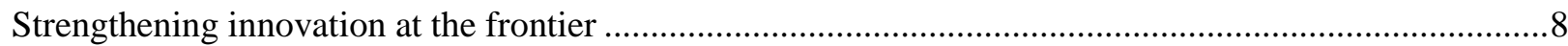

Tax incentives are generally supportive of R\&D investment but could be streamlined .........................

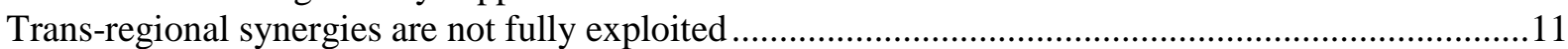

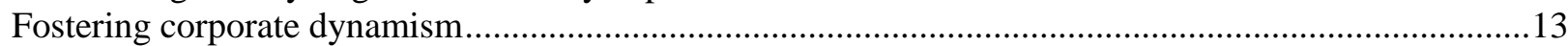

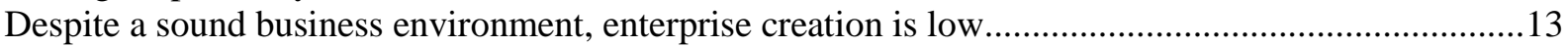

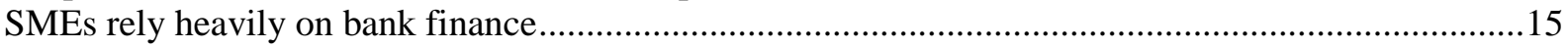

Low enterprise culture influences rates of enterprises dynamism..................................................... 17

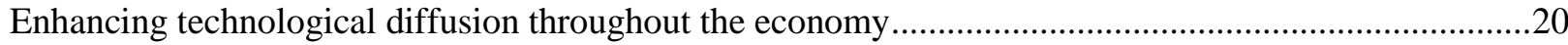

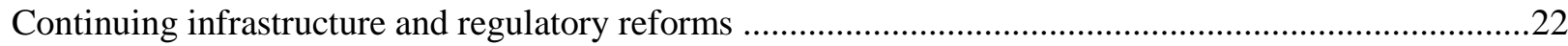

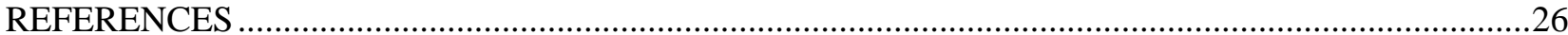

\section{Tables}

1. The productivity gap widens with distance to multinationals

\section{Figures}

1. The level of productivity is high but productivity growth has slowed .............................................6

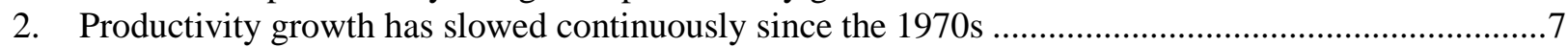

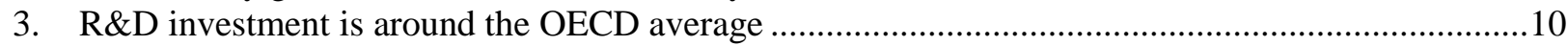

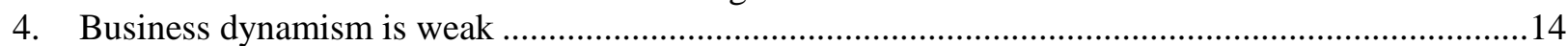

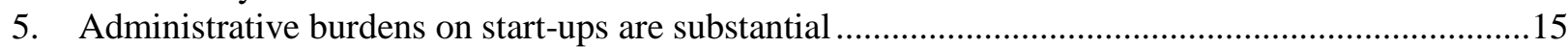

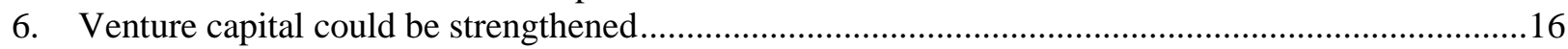

7. More should be done to foster entrepreneurship culture ..............................................................18

8. Intellectual asset generation and commerciatisation are relatively weak .........................................19

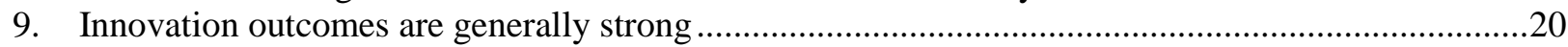

10. The distribution of labour productivity across firms is wide .....................................................20

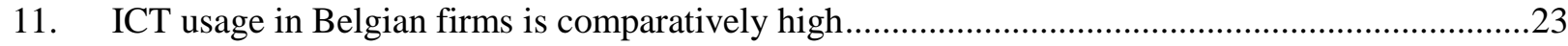

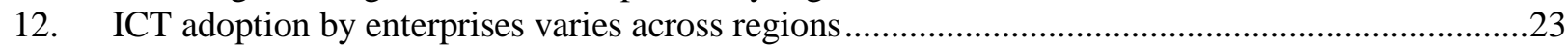

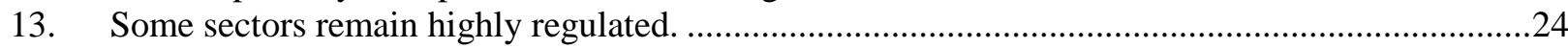

\section{Boxes}

Box 1. The decline in productivity growth is partly a composition effect.............................................

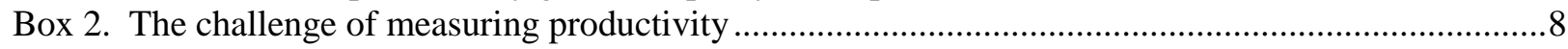

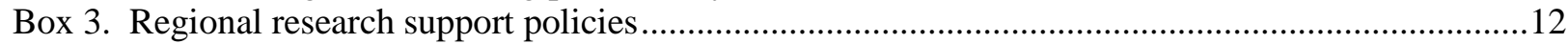

Policy recommendations on improving the business environment ......................................................25 
ECO/WKP(2017)83

\title{
MAKING THE BUSINESS ENVIRONMENT MORE SUPPORTIVE OF PRODUCTIVITY IN BELGIUM
}

\author{
By Peter Walkenhorst, Lilas Demmou and Manav Frohde ${ }^{1}$
}

\section{Introduction}

Productivity has been a key driver of economic growth and prosperity in Belgium. GDP per hour worked amounted to USD 63 in 2015 (in 2010 PPP), which was a third higher than the OECD average and next only to labour productivity in Luxembourg, Norway and Ireland (Figure 1.A). The high productivity level is the result of substantial capital deepening in the past; a highly-qualified workforce and strong multifactor productivity (MFP), in particular in the lead manufacturing sectors: chemicals and chemical products, and basic metal and fabricated metal products (Dumont and Kegels, 2016; Biatour et al., 2008). However, the growth in productivity has slowed over time. A similar deceleration in MFP growth occurred for most OECD countries, but it has been more pronounced in Belgium (Figure 1.B and C). In particular, the 2008 financial crisis led to negative labour productivity growth rates in many OECD countries in 2008 and 2009, as companies retained workers while output declined. Belgium's productivity briefly recovered in 2010, but subsequently fell back and only picked up again in 2014 and 2015. A part of the recorded productivity slowdown is related to changes in the composition of the Belgian economy (Box 1), as well as from problems of accurately measuring quality improvements stemming from new information and communication technology (ICT) products and services (Box 2).

Given the central importance of productivity for economic prosperity, an important challenge for policy-makers is to identify and implement measures to lift productivity growth. Growth should also be inclusive, so that all share in rising incomes, if it is to be sustainable in the longer term. Belgium ranks relatively well on many of the key determinants of productivity growth such as overall business environment, skills and innovation indicators. The recent OECD flagship report on The Future of Productivity (OECD, 2015a) identifies two main avenues through which productivity growth can be enhanced: creating a business environment that facilitates innovation and widespread distribution of advanced technologies; and improving resource allocation within the economy, notably by better matching employee skills with workplace requirements. This chapter discusses the role of various areas of the business environment in productivity performance, including innovation management, technological diffusion, private and public sector investment, and regulatory and competition policies.

1. Peter Walkenhorst is professor of Economics the American University of Paris. Lilas Demmou and Manav Frohde are members of the OECD Economics Department. The authors would like to thank Piritta Sorsa, Alvaro Pereira, Robert Ford and Olivier Durand-Lasserve from the OECD Economics Department for valuable discussions and feedback on earlier drafts. Special thanks to Lenka Wildnerova from the OECD Economics Department for her analysis of productivity in Belgium and to Bert Brys from the OECD Center for Tax Policy and Administration for his comments on tax policies in Belgium. The authors would also like to give special thanks to Pedro Herrera-Gimenez for statistical support and Anthony Bolton, Brigitte Beyeler, Raquel Paramo and Mercedes Burgos for administrative and editorial assistance, all from the OECD Economics Department. 
Figure 1. The level of productivity is high but productivity growth has slowed

A Labour productivity is one of the highest in the OECD GDP per hour worked, 2016 or latest available (USD 2010 PPPS)

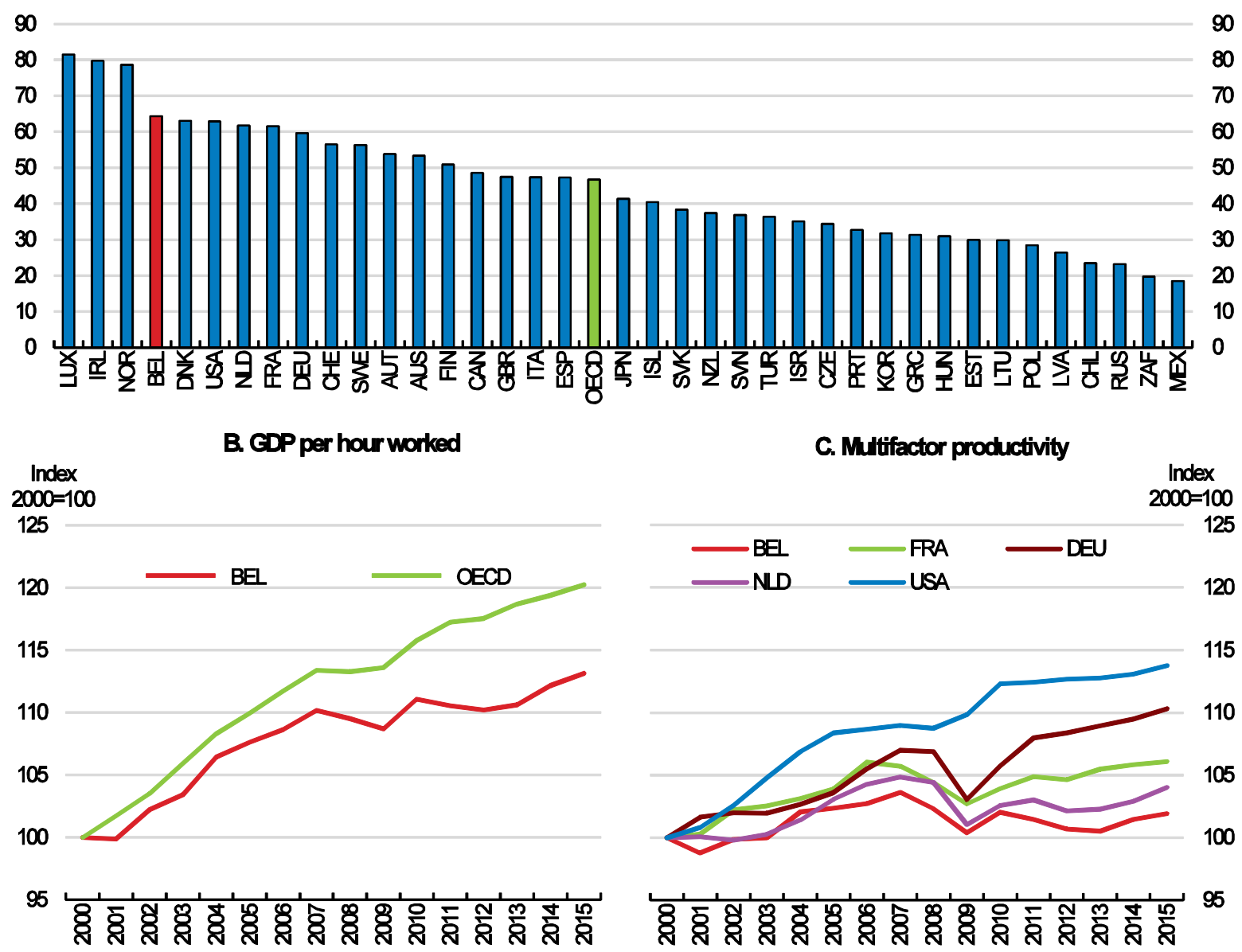

Note: For Australia, Belgium, Chile, Iceland, Ireland, Japan, Korea, Mexico, Poland, Russia, South Africa, Turkey and United States, data refer to 2014 in the panel $B$.

Source: OECD Productivity Statistics Database; and The Conference Board Total Economy Database. 


\section{Box 1 . The decline in productivity growth is partly a composition effect}

The productivity slowdown in Belgium began in the mid-1970s (Figure 2). Part of this slowdown is due to changes in the composition of the Belgian economy. Shift-share analysis of labour productivity growth at the two-digit industry level over the period 2000-2014 shows that the intra-industry effect, which represents productivity growth in individual industries, was higher than aggregate labour productivity growth. This suggests that industries with higher productivity growth decreased their share in total employment (Dumont and Kegels, 2016). The structural or inter-industry effect, which captures the reallocation of labour resources between industries, was slightly negative over the same period, implying an expansion of low-productivity sectors, such as non-tradable services, relative to high-productivity sectors.

Figure 2. Productivity growth has slowed continuously since the 1970 s

GDP per hour worked (USD, current PPPS)

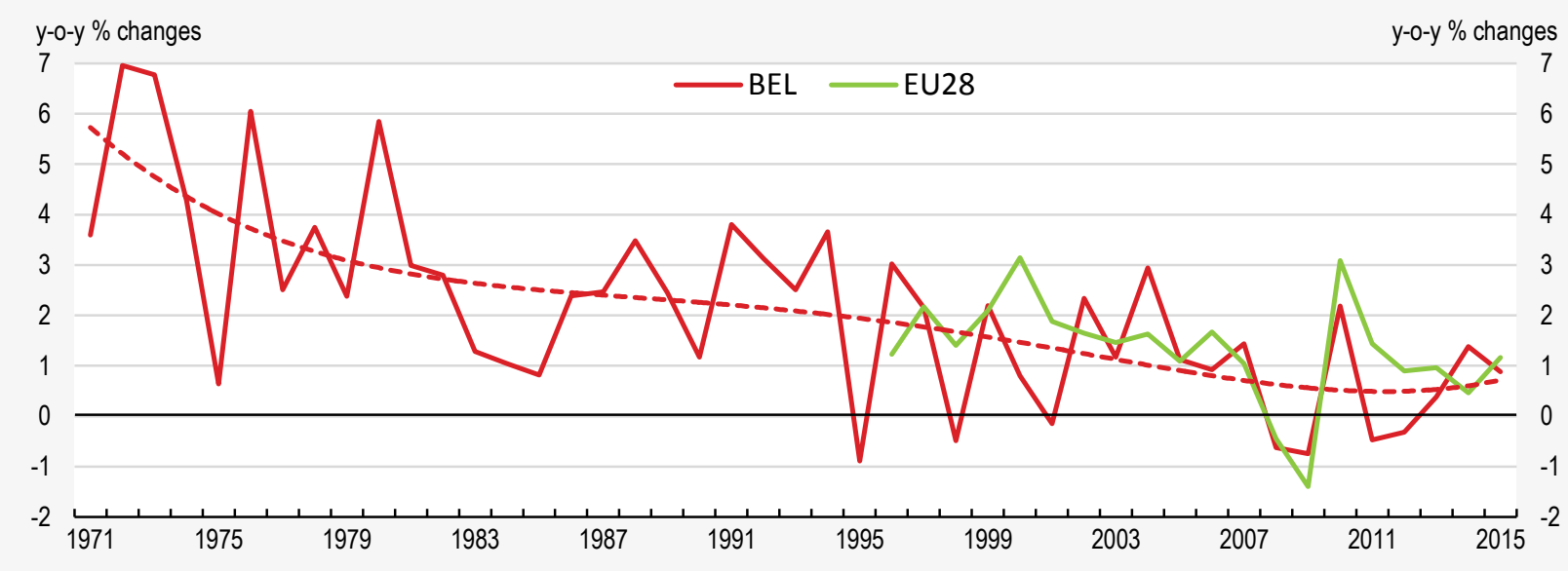

Source: OECD Productivity Statistics Database.

Another composition effect comes from labour market reforms that integrated low-productivity workers into the economy and thereby depressed average productivity (Boulhol and Turner, 2009). In 2003, the Federal government introduced service vouchers, which provide a wage cost subsidy for labour-intensive, low-skilled household work. The measure also aimed to transform previously undeclared work into regular jobs. The policy proved popular and uptake was high. Over the period 2000-2014, employment growth in "Administrative and support service activities" increased from $5 \%$ of total hours worked in the Belgian economy to almost $8 \%$. This employment category experienced the strongest decrease in productivity growth during the period, pointing to important trade-offs between productivity and inclusiveness.

Another factor that has contributed to the deceleration of productivity growth in Belgium is population ageing. One study found that the cumulative multifactor productivity of the Belgian workforce declined by 4.5 percentage points as a result of the increase in the share of older workers in total employment (Ariu and Vandenberghe, 2014). Workers above 55 years of age were found to be almost a third less productive than their colleagues in their late 30 s. 


\section{Box 2. The challenge of measuring productivity}

Over the past decade, productivity growth has slowed markedly in many OECD countries. This broadbased decline is puzzling, since technological innovations have continued strongly. Some analysts have suggested that productivity growth may be underestimated (Derviş and Qureshi, 2016; Ahmad and Schreyer, 2016).

An important source for the underestimation of productivity is related to the fact that quality improvements in new information and communication technology (ICT) products are not fully reflected in prices or are not fully adjusted for by statistics agencies. As a result, price deflators will be biased upwards and real output will be underestimated. Second, some internet-based services, such as search engines and social media networks, are provided free of charge. Their consumption, is therefore not taken fully into account in GDP measurements, even though these services provide significant utility for consumers.

While mismeasurement cannot explain the full magnitude of the observed decline in productivity (Syverson, 2016), it is difficult to track the impact of ICT innovations and digital services. As the composition of ICT innovations shifts from hardware to software, the impact of new technologies on productivity becomes more difficult to predict and could well differ substantially across applications or sectors, by, for example raising quality in some cases while reducing costs in others. Moreover, the structural change in economies with a relative strengthening of services sectors might amplify mismeasurements if quality adjustments for digital inputs used in these services are not properly captured. Thus, statistics experts and analysts should pay close attention to the digital measurement challenge in order to maintain high quality productivity data.

\section{Strengthening innovation at the frontier}

One key determinant of productivity growth is the extent to which new products, processes and organisational know-how are developed by frontier firms. Public policy has a key role to play in this context. In particular, strengthening firm-level innovation and investment in research often requires public financing of basic research to support the continued emergence of breakthrough innovations. Moreover, public entities can frequently act as catalysts for collaboration between firms, research labs, and universities.

\section{Tax incentives are generally supportive of $R \& D$ investment but could be streamlined}

The European Innovation Scoreboard 2016 classifies Belgium as a "Strong Innovator", with a normalised score of 0.6. This falls short of the 0.7 of top ranked Sweden and Denmark, but exceeds the EU28 average of 0.52. Investment in intangibles such as research and development (R\&D) is important to boost productivity (Andrews et al., 2015). At 2.5\% of GDP in 2014, Belgium's gross spending on R\&D was higher than both the EU and OECD averages (Figure 3.A), but fell short of the Lisbon target of 3\%. Publicly financed expenditure on R\&D has been expanding by an annual average growth rate of $7 \%$ since 2008 and amounted to $0.72 \%$ of GDP in 2013, exceeding the OECD average of $0.61 \%$.

Most R\&D occurred within manufacturing, notably through firms in the pharmaceuticals, chemicals and bio-tech sectors, and more than half of all business enterprise R\&D (BERD) was carried out by foreign affiliates (Figure 3.C). However, not all R\&D is necessarily concentrated in large firms. Firms below 250 employees accounted for 35\% of all BERD in Belgium in 2011(OECD, 2013a). The share of gross domestic expenditure on R\&D (GERD) that is financed by the business sector has declined over the past two decades (Figure 3.B). Business expenditure on R\&D tends to be concentrated in firms that are already highly productive and want to stay at or reach the technological frontier (Andrews et al., 2015, Figure 3.C). Therefore, the challenge for Belgian policy-makers is to induce more such firms to expand their investment in $R \& D$ intangibles. 
The federal and regional governments have launched a number of programs to foster firm-level R\&D and innovation. Science, technology and innovation are largely a sub-federal responsibility. Scientific research is mainly a Community competence, whereas innovation is almost entirely a regional responsibility. Following consecutive state reforms which devolved many spending areas, around $80 \%$ of total public R\&D and innovation support derives from the communities and the regions. The remaining part of support consists of resources from EU projects or federal initiatives. The latter are related to a partial exemption of withholding tax on researchers' wages, tax deductions on investments that stimulate R\&D and innovation, and tax deductions on patent income. The Federal government also retains responsibility for research infrastructure of national interest, several scientific institutes, and a small number of research programmes (climate change, nuclear energy, space policy and polar research). It also sets the framework conditions in areas such as intellectual property rights, normalisation, standardisation, and scientific visas.

The tax credit system is being reformed. Since 2008 firms have been entitled to an $80 \%$ tax deduction on income from patents. This patent box regime was abolished in July 2016, with a five-year grandfathering period for patent applications submitted before 1 July 2016. The objective was to bring the new regime in line with the OECD G20 minimum standards of a "modified nexus approach", which requires substantial activity in IP regimes (OECD, 2014). Furthermore, a new innovation income deduction regime has recently been approved aiming to widen the scope of qualifying innovation income (such as licenses and exclusive rights), while restricting deductibility according to the "Nexus" rules. In this context, the authorities should make sure, for example through careful monitoring, that a strong link between the tax incentive and R\&D spending is established and that the support granted is not merely used by firms as a tax planning tool.

Another incentive scheme consists of deductions for R\&D-related investments and patents. Investments in assets that promote $R \& D$ and advanced technologies that are environmentally friendly, as well as investments in R\&D that result in self-developed patents or in the acquisition of patents, benefit from a $13.5 \%$ tax deduction on the investment value. The deduction can be carried forward for an unlimited period. Alternatively, the support can take the form of an R\&D tax credit, which offers the same tax benefits as the investment deduction, but the part which is not used after five years is refunded. Other OECD countries operate similar R\&D tax credit programmes, with some, such as the French Crédit d'impôt recherche (CID), providing a tax credit of up to 30\% of R\&D expenses (up to EUR 100 million), while other countries are far less generous than in Belgium. Overall, Belgium provides the most generous R\&D incentives in the OECD (OECD, 2016a). 
Figure 3. R\&D investment is around the OECD average

A. Gross domestic expenditure on R\&D

As a percentage of GDP, 2015 or latest available

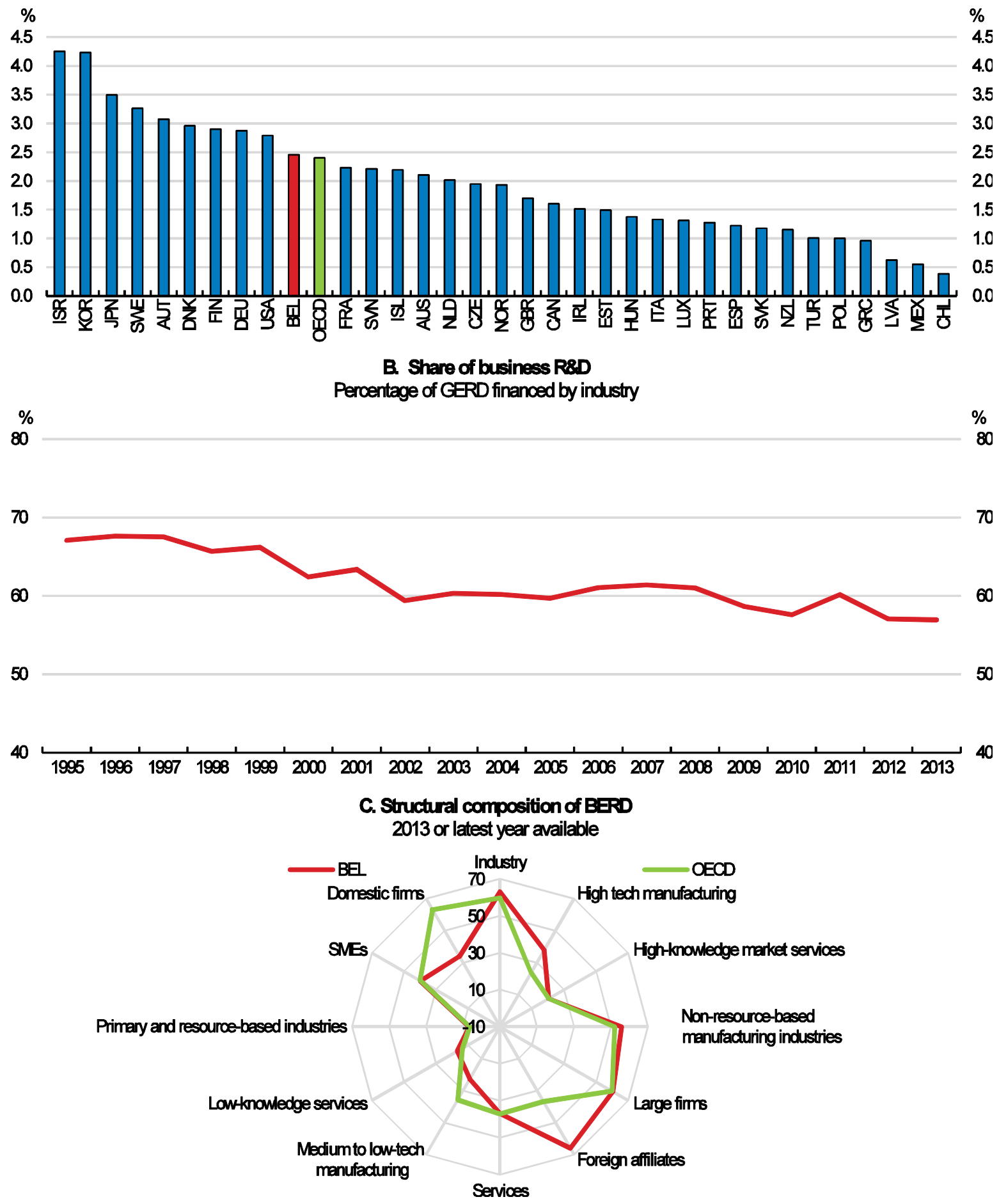

Note: For Australia, Canada, Ireland and Turkey, data refer to 2014.

Source: OECD, Main Science \& Technology indicators; and OECD, Science, Technology and Innovation Outlook 2016. 
Federal authorities also support R\&D by allowing firms to recover up to $80 \%$ of the withholding tax on professional wages for their researchers, providing certain conditions are met. In particular, there is an upfront reporting obligation on the nature and duration of research projects to the Belgian Science Policy Office (BELSPO). The partial exemption of wage withholding tax on researchers' salaries corresponds well to the principle that R\&D incentives should be focused on those types of expenditures that bring about strong knowledge spill-overs (Straathof et al. 2014). Also, tax incentives related to R\&D wages generally tend to have low administration and compliance costs.

\section{Trans-regional synergies are not fully exploited}

The regions and communities have developed their own complementary set of research-support policies, which were slightly expanded after taking over additional responsibilities for some R\&D activities upon the Sixth State Reform of 2012-2014 (Box 1.3). Regional and community R\&D promotion policies largely consist of direct support and thereby complement the indirect support (tax incentives) provided by federal authorities. This is a welcome policy practice (Appelt et al., 2016). Key policy frameworks for R\&D support are provided in the Flemish Region's Governing Agreement (2014-19) and Policy Note 2014-2019, the Walloon Region's Marshall Plan 4.0 (2015-19), and the Brussels-Capital Region's Regional Innovation Plan (2015-20). In 2013 total R\&D expenditure by region varied from $2.85 \%$ of GDP in the Walloon Region to $2.52 \%$ in the Flemish Region and $1.52 \%$ in the Brussels-Capital Region. Several structural factors explain the relatively weak R\&D intensity in the Brussels-Capital Region: the strong presence of low-skilled services activities, the scarcity of high and medium-technology manufacturing industries, and the weak representation of corporate headquarters of industrial companies, which are often located in the other Belgian regions or abroad (Kalenga-Mpala and Wautelet, 2016). In Flanders and Wallonia, private sector R\&D spending relative to GDP exceeds the EU28 average, while the share of publicly funded R\&D in GDP is below the EU average. In the Brussels Capital Region, the reverse is the case.

The regional innovation programmes provide considerable variety in terms of support activities. The authorities are aware that too large a fragmentation of programmes and executing agencies could be detrimental to transparency and cost efficiency. For example, Flanders commissioned an evaluation of its innovation support landscape (Soete, 2012) and has consolidated its activities based on the assessment's recommendations. As of 2016 there is a single agency for all business support and a single agency for researchers' support in the Flemish region. Also, the agreement on the inter-university attractiveness poles between the French and the Flemish Communities is a good example of cooperation. The French Community and the Walloon Region decided to establish a common roadmap in the context of the European Research Area (ERA) framework. Such cooperation has led to more coherence between similar programmes offered in different regions (EC, 2016a). Going forward, continued streamlining of programmes within each region and more developed cooperation between regions and with communities would strengthen the efficiency of regional support for innovation (EC, 2016b). The Flemish Region, the Brussels-Capital Region, and the federal authority have also drafted their own ERA roadmaps. 


\section{Box 3. Regional research support policies}

The Flemish authorities have established a number of R\&D funding options. Feasibility studies are eligible to receive funding for up to $50 \%$ of costs, with a ceiling of EUR 50 000; SME innovation projects are eligible for up to $45 \%$ for small enterprises and $35 \%$ for medium-sized enterprises (with a ceiling of EUR 250 000). The development of new innovative products are eligible for $25 \%$ for development activities, and $50 \%$ for industrial research activities (with a ceiling of EUR 250 000). Projects to gain new knowledge to realise an important innovation are eligible for 25\% (with a ceiling of EUR 250 000); and pre-doctoral researchers can obtain a $50-60 \%$ fellowship for up to four years if they co-operate with private companies in a specific sector.

In the Walloon Region, financial support is granted for feasibility studies, covering between 40 and $75 \%$ of expenses incurred by external service providers; basic industrial research is eligible for funding of up to $50 \%$ expenses; applied research or technological development is eligible for funding for between 50 and $75 \%$ of admissible research costs; patent registrations may receive financial aid of between 35 and $70 \%$ of registration costs; and managerial costs of enterprise spin-offs may receive support for the first two years.

In the Brussels-Capital Region, the creation of new companies (spin-offs) is supported with grants of 25$75 \%$; industrial research projects can receive financial aid of $50-70 \%$ of eligible costs; participative research and social innovation for urban resilience can benefit from support of between $25 \%$ and $70 \%$ of outlays; experimental development projects can receive grants of $25-45 \%$ or advances of $40-60 \%$ of eligible expenses; implementation of process innovations is supported with $15-35 \%$ of the costs; the preparation of feasibility studies can be subsidised by $50-75 \%$, and $35-70 \%$ of the costs of obtaining and validating patents can be financed by the region

The regions also provide support to innovators by nurturing innovative economic clusters, simplifying government aid procedures, and reducing administrative burdens. These initiatives differ in line with regional characteristics and policy priorities. For example, industrial cluster promotion is among the main policy aims in the Flemish and Walloon Regions, while cluster policies are more focused on services in Brussels. All the cluster programmes seek to form or reinforce networks among public and private entities, including companies, universities, polytechnics, training organisations, and research centres, with the aim of stimulating project partnerships and innovative value chains in areas in which the regions already have some potential.

Flanders has adopted a smart specialisation strategy that prioritises support for eight different domains: sustainable chemistry, specialised manufacturing solutions, personalised cure and care, valueadded logistics, specialised agro-foods, an integrated building-environment-energy cluster, and new ICT platforms. In the Walloon Region, support is available through the region's Marshall Plan for six competitiveness clusters: transport and logistics; aerospace; green chemistry and durable materials; biotechnology and health; food; and mechanical engineering. In the Brussels-Capital Region, there are five clusters: eco-construction; biotechnology, pharma and medical activities; software production; audiovisual production, post-production and distribution; and green technologies. Three of these clusters correspond to the region's smart specialisation priorities; namely personalised medicine, green economy, and digital economy. Also, all regions provide overarching frameworks in accordance with the EU's Small Business Act to foster entrepreneurship, simplify the regulatory and policy environment for SMEs, and remove barriers to their development. In 2016 Flanders introduced a "New Cluster Policy" based on two types of clusters: small-scaled innovative business networks (fourteen of which were approved for public support), and on the other hand spearhead clusters (at present five have been approved, namely in the domains of sustainable chemistry, logistics, materials, energy and agro-foods). 
In 2014, the Walloon Institute for Evaluation, Prospective and Statistics published a set of recommendations for the future development of the region's cluster policy based on a detailed evaluation (Iweps, 2014). Some of the key suggestions for improvement included the need for better coordination of cluster activities with other governmental programmes, stronger monitoring of cluster projects and their impact, improved integration of training components in other cluster activities, and stronger emphasis on marketing and consumer-orientation. Similar evaluations of the cluster programmes in the other regions could help inform the policy-making process.

\section{Fostering corporate dynamism}

\section{Despite a sound business environment, enterprise creation is low}

Young firms often have an advantage in commercialising radical innovations (Baumol, 2002), and a vibrant start-up culture is conducive to high productivity growth. The World Bank's Doing Business 2017 report ranks Belgium 17th out of 190 countries for starting a business (WB, 2016a), making it the 9th best ranked OECD country. Belgium scores better than the OECD average for procedures, and time and costs to start a company. Belgium also scores well for bankruptcy procedures, another requisite for a strong start-up culture (Calvino et al., 2016). In "resolving insolvency" Belgium ranks 10th out of 190 countries and 9th among OECD countries.

Despite the Relative ease at which a firm can be established (and shut down), Belgium, somewhat surprisingly, had the lowest enterprise birth and death rates among all EU15 countries in 2014 (Figure 4.A). On the other hand, Belgium has the highest average post-entry employment growth of surviving entrants (over a seven-year period following establishment) among all participating countries in the OECD's Dynemp project (Figure 4.B), suggesting that once established, firms tend to prosper. 
Figure 4. Business dynamism is weak

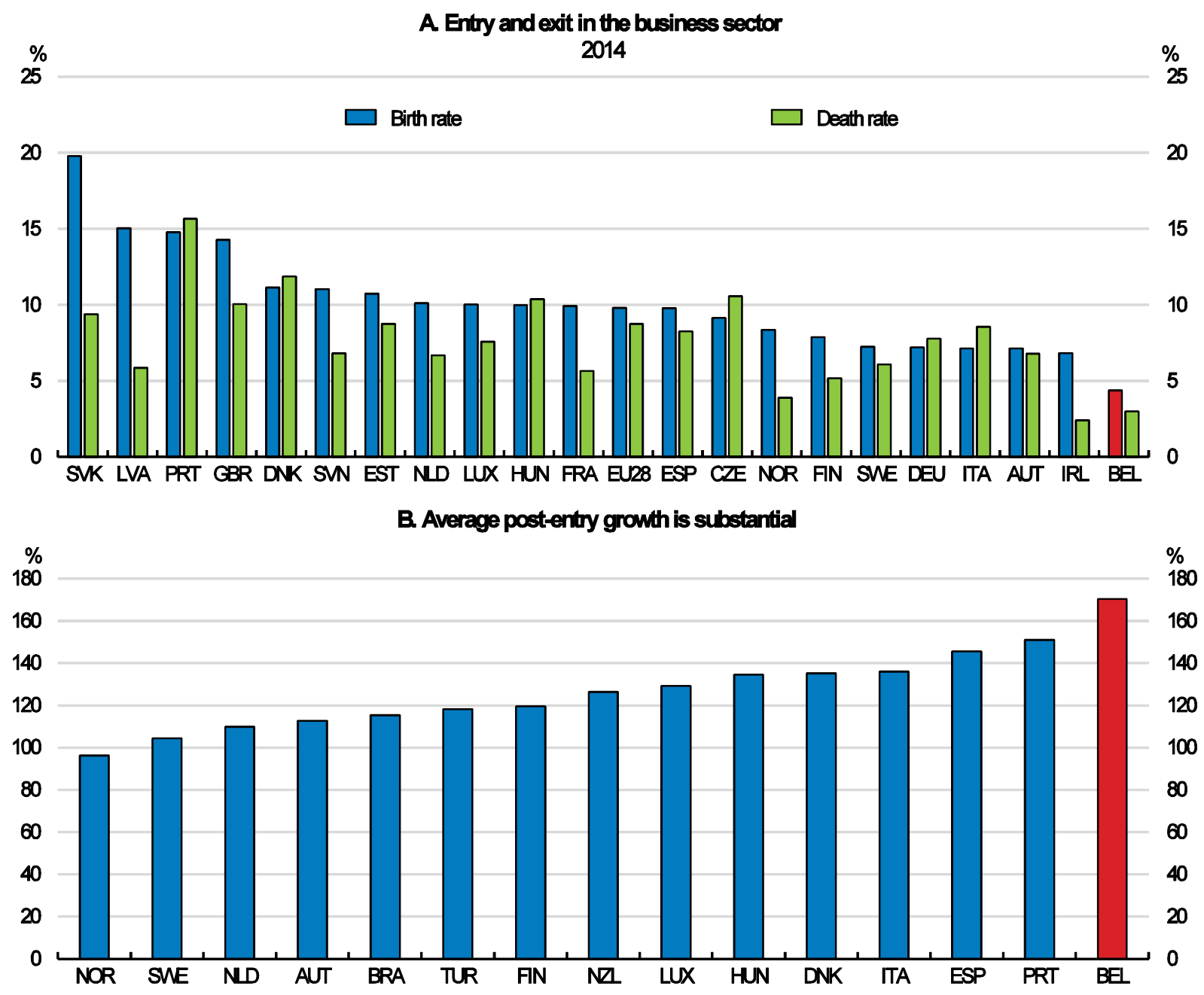

Note: Average post-entry growth defined as the ratio of total employment at $t+3$ to total initial employment of surviving entrants.

Source: European Commission and; Calvino et al. (2016).

The low birth and death rates might be related to the dominating presence of large, established firms, which do not leave sufficient space for newcomers (Calvino et al., 2016), while the strong postestablishment growth may reflect the generally favourable business environment. Yet, some aspects of the regulatory framework could be improved. In particular, high minimum capital requirements may act as a financial barrier to start a business. Another area where Belgium's performance is relatively weak is "enforcing contracts": the country ranks 50th overall and is number 23 among OECD countries mainly due to low scores for court automation and case management (WB, 2016a).

To encourage start-up enterprises, the Federal government is implementing measures within its "SMEs plan" of February 2015 to reduce the administrative costs associated with firm registration by 30\%, for example by creating a single administrative contact for SMEs, the Banque-carrefour des Entreprises, and systematically disseminating information and tender documents to SMEs that have expressed interest in certain types of tenders. These efforts reduce the comparatively high administrative burdens on start-ups (Figure 5). Federal initiatives are complemented by regional efforts to simplify administrative procedures for SMEs and rationalise business support services, notably by establishing single contact points for all administrative procedures. 
Figure 5. Administrative burdens on start-ups are substantial

Barriers to entrepreneurship, administrative burdens on start-ups, 2013

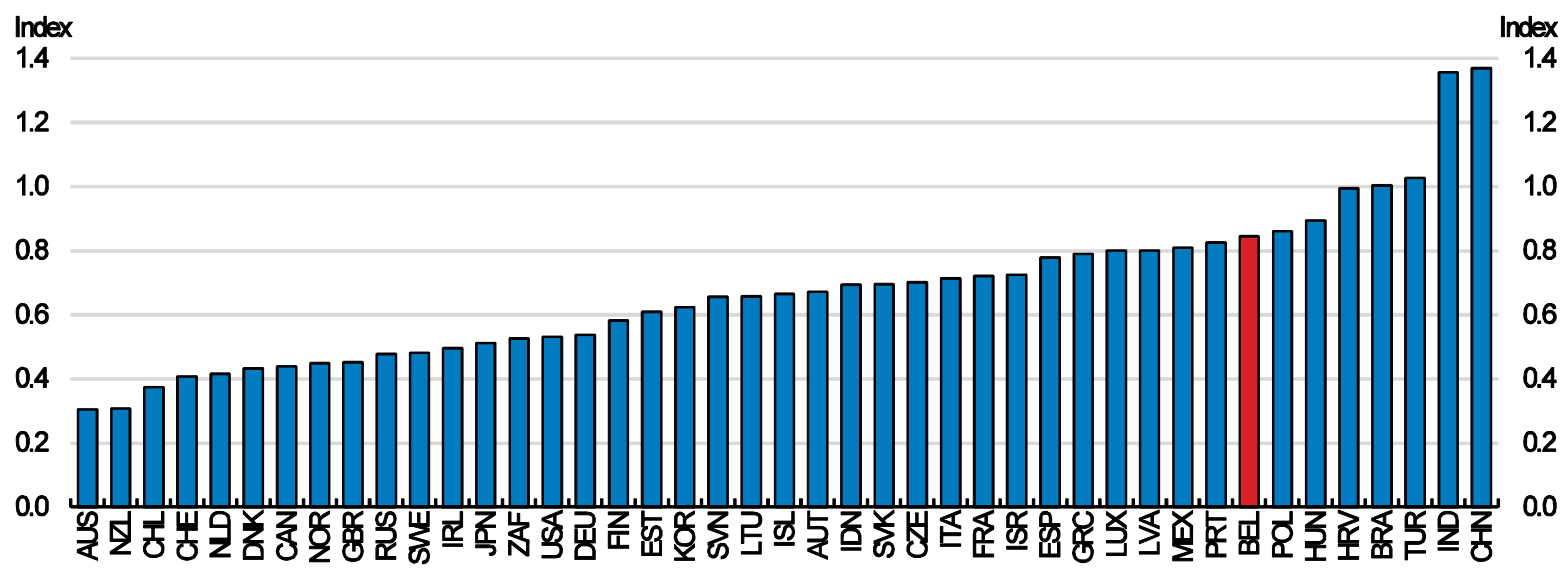

Source: OECD, PMR indicators database.

Some elements of the Belgian tax system might hamper growth of young firms and discourage firm creation. In particular, as many other countries, Belgium exempts small companies from registration for value added tax (VAT) to simplify tax procedures and lower administrative costs. However, the threshold from which registration is required is relatively low, and, across EU countries, low VAT thresholds are associated with low rates of business entry (IMF, 2016). The Belgian authorities are aware of the potentially detrimental impact of a very low VAT registration threshold raising it to EUR 25000 as part of the reforms of the "SMEs plan" of 2015.

\section{SMEs rely heavily on bank finance}

While access to finance is not a significant impediment to the business sector at the macro level (WB, 2016a), young innovative firms face financing constraints, particularly in the scale-up phase, and SMEs more broadly rely heavily on banks. In 2014, the Belgian Federal Public Service of Economy, SMEs, Self-employed and Energy conducted a survey on the financing of SMEs (SPF Economie, 2015). The results indicate that firms below four years of age are far more dependent on bank loans than older companies, who can draw on retained earnings to finance their operations. About $68 \%$ of Belgian start-ups applied for bank loans in 2014, but only one-third of the total applications were approved. For firms older than four years, the approval rate was $83 \%$. According to a European Central Bank (ECB) survey, in both 2015 and 2016 roughly $35 \%$ of Belgian SMEs reported having applied for a bank loan during the past six months, which is among the highest rates in the EU (ECB, 2015; 2016).

The heavy dependence on bank finance makes the SME sector vulnerable to downturns. Although there was no credit crunch, increased risk-aversion led banks to tighten credit standards for SMEs during the crisis years of 2008 and 2009 (Piette and Zachary, 2015; Wilson and Silva, 2013). To broaden the range of funding options the government could promote the use of small-scale debt instruments and securitised receivables. Such instruments would allow SMEs to access capital markets directly without obtaining a credit rating or preparing a prospectus (HLEG, 2016). High quality securitisation of SME loans (and other liabilities such as leasing) can be used as a market-based shortcut to indirectly promote SME financing, without the complete disintermediation of banks (Nassr and Wehinger, 2015). Private placements also offer an alternative to public corporate bond issuance, providing a source of funding 
without the need for a formal credit rating or reporting requirements common for other capital market debt products (OECD, 2015c).

Increased integration through the Capital Markets Union could also help diversify Belgian capital markets. In this context, the government is supporting private equity finance for SMEs to strengthen the provision of venture capital (Figure 6) and improve access to finance for start-ups. Closed-end investment funds ("Pricafs Publiques") that raise a fixed amount of capital through an initial public offering and are listed on the stock exchange have been in existence since 1997. However, substantial disclosure and transparency requirements have deterred many SMEs from using publicly listed funds. Less stringent listing rules and requirements for small equity issuers could allow for more affordable transaction and regulatory costs for small equity issuers without undermining investor protection and market integrity (Nassr and Wehinger, 2016). Moreover, stringent regulations on dividend pay-outs and portfolio management often made the funds unattractive to investors, so that only one such fund ("Quest for Growth") remained in existence by mid-2016.

In August 2016 new legislation was introduced to bolster the development of Pricafs Publiques. In particular, the obligation to pay an annual dividend was dropped and fund managers were granted greater flexibility in shaping investment portfolios. For instance the share of funds that have to be invested in unlisted firms with a market capitalisation of less than EUR 1.5 billion was reduced from $100 \%$ to $70 \%$.

Figure 6. Venture capital could be strengthened

As a percentage of GDP, 2015

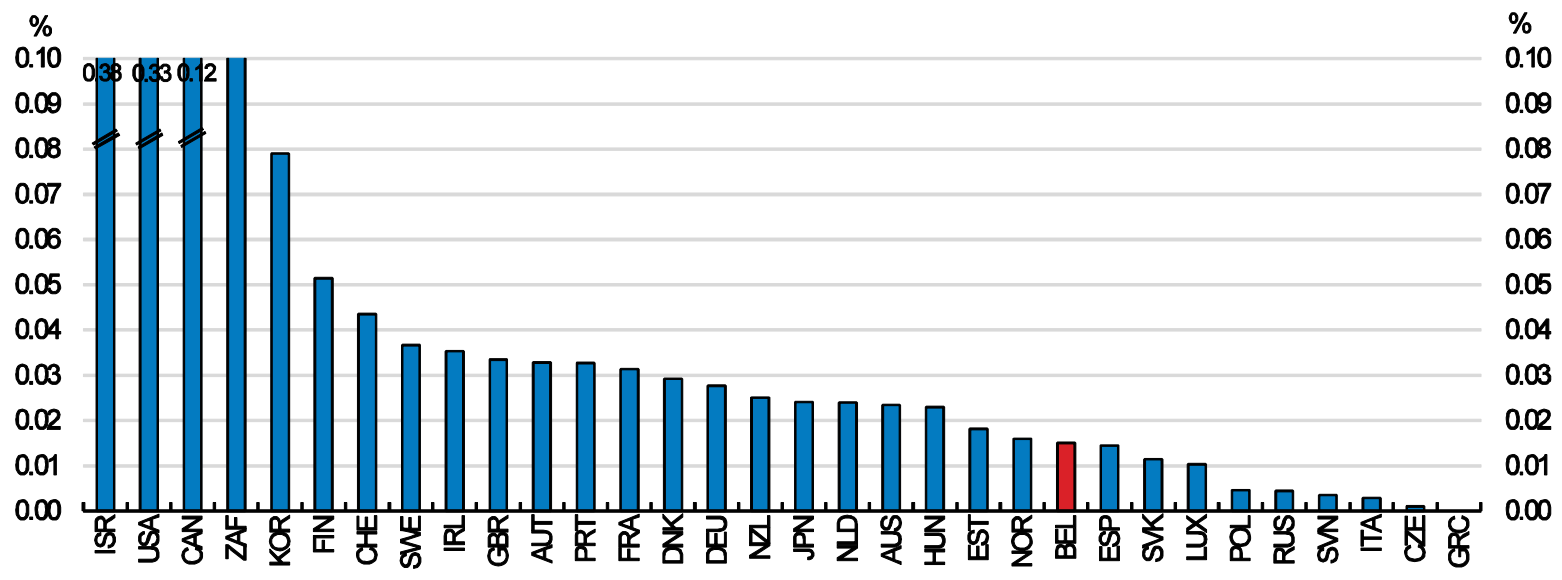

Source: OECD, 2016d.

The authorities run a range of other initiatives to improve funding for SMEs. Guaranteed loans and guarantees given by public sector entities partially offset negative growth rates in the stock of loans from banks to businesses in 2009 and 2013 (OECD, 2016b). Moreover, since 2003 privately-held Pricafs Privés (managed financial funds) have provided unlisted SMEs with an alternative source of risk capital. These funds allow investors to benefit from professional management and risk pooling without incurring a fiscal penalty compared to direct investments. By the end of 2016, 42 Pricaf Privés were registered with the Finance Ministry.

In July 2015 the federal authorities introduced a new tax shelter for start-ups and small enterprises less than 4 years old. Under this scheme, individuals investing in a start-up company can obtain an income 
tax reduction of $30 \%$ of an investment in an SME, and of $45 \%$ for an investment in micro-enterprises. A person can benefit from this tax-shelter for investments up to EUR 100000 per year, with a cumulative investment ceiling of EUR 250000 . The investments can be made either directly or indirectly through a crowdfunding platform, but have to be held for at least four years. In addition, start-up labour costs are being reduced during the first years of operation, with the young companies being exempted from payment of $10-20 \%$ of the withholding tax applied to wages. Also, digital goods, such as payment systems and cyber-security, benefit from a tax exemption of $13.5 \%$ of the invested amount.

The federal efforts to improve access to finance for start-ups and SMEs are supplemented by regional initiatives. In particular, all regions offer financial assistance to regional business angel networks ("beangels" in the Brussels-Capital Region and the Walloon Region; "Business Angels Netwerk" in the Flemish Region). Furthermore, the Flemish Region has been offering win-win-loans ("winwinleningen") since 2006. Under this scheme, investors in SMEs can deduct 2.5\% of any outstanding loan volumes from their income tax. An SME can borrow up to EUR 200000 under the facility. In April 2016 the Walloon Region introduced a similar scheme ("Prêt coup de pouce"), which differs in some aspects. Support is limited to start-ups for a duration of up to eight years, and the ceilings are set at EUR 100000 per firm and EUR 50000 per lender. Individual lenders benefit from a tax deduction of $4 \%$ of the invested amount during the first four years and $2.5 \%$ thereafter. However, while regional authorities have taken steps to simplify support schemes and make them more accessible to firms, better coordination between different government entities could reduce information and search costs for SMEs and help ensure a more efficient allocation of available funds (HLEG, 2016). In addition, a more neutral tax treatment of income from savings deposits could improve the effectiveness of existing tax incentives for retail investors-based SME financing.

Evidence increasingly suggests that firm age, and not necessarily firm size, is the most decisive factor for net job creation and productivity growth (OECD, 2015a). Also, size-based taxes and social security or labour advantages may create disincentives for companies to grow, thereby creating a small business trap (IMF, 2016). In this context, the more focused support provided in the Walloon Region is welcome, and the Flemish authorities might want to consider targeting their tax deductions more directly at start-ups and young firms.

\section{Low enterprise culture influences rates of enterprises dynamism}

Recent empirical work found that with respect to the regulatory framework, market conditions, access to finance, and entrepreneurial capabilities, Belgium scores favourably in comparison with the EU average (De Mulder and Godefroid, 2016; OECD, 2015d). However, Belgium comes last in terms of enterprise culture, which captures factors like job prestige and risk aversion (Figure 7). These findings suggest that the authorities should continue to strengthen entrepreneurship education and better inform young graduates about the nature and opportunities of private business. Case study evidence from initiatives to foster a more entrepreneurial culture in East Germany also suggest that the creation of identifiable role models and champions, as well as the establishment of mentor and patron panels of retired business people that counsel company founders can be beneficial (Bergmann, 2007). Regional authorities could thus consider expanding existing mentor programmes. 
Figure 7. More should be done to foster entrepreneurship culture

Relative performance to the EU, 2009-15

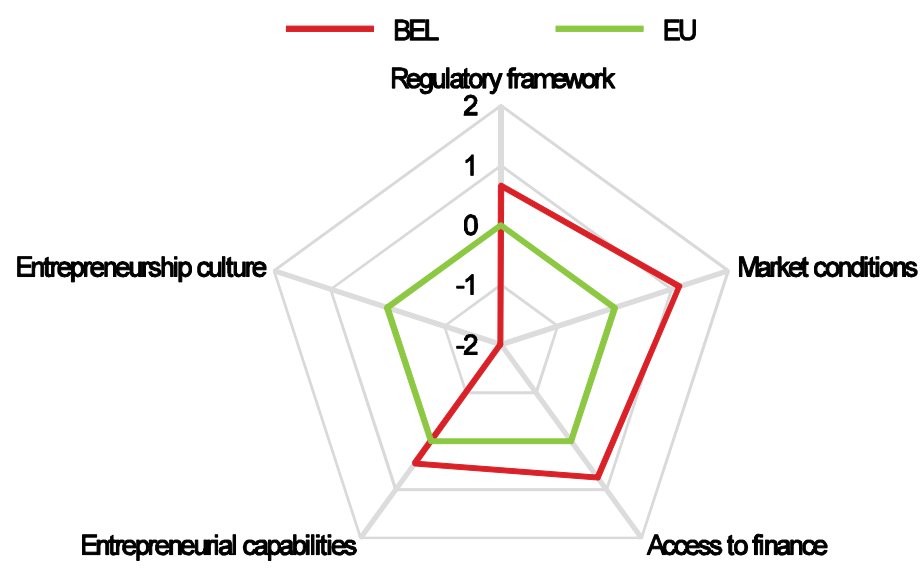

Note: Lower scores indicate lower performance. Scores are expressed relative to EU average equal to zero for each indicator. For EU, data refer to the unweighted average of scores calculated for Austria, Belgium, Denmark, France, Germany, Greece, Ireland, Italy, Luxembourg, Netherlands, Portugal, Spain and Sweden.

Source: De Mulder and Godefroid, 2016; OECD, 2015d.

One innovation area where Belgium does not score well relative to the EU average is patenting (Figure 8). This finding may to some extend reflect Belgium's industrial structure, which is not focused on high-tech activities. To encourage potential innovators to undertake research and development, effective protection of intellectual property rights is important. Belgium ratified the regulation concerning the European Patent with Unitary Effect in June 2014, and are considering establishing a local division of the Unified Patent Court in Brussels that works in English as well as in the national languages. The European patent provides firms with an opportunity to obtain legal protection for their innovation in the 26 participating EU countries without applying for protection in each individual member state. This reduces costs and administrative work involved with patent filing. Belgium also implemented the London Agreement on the application of Article 65 of the European Patent Convention by the Act of 29/6/2016 by removing the requirement to provide a translation to a national language of a European patent granted in English from the code of economic law and from other legislation. 
Figure 8. Intellectual asset generation and commercialisation are relatively weak

Relative performance to the EU, 2015 or latest available

$\mathrm{BE} \quad \mathrm{EU}=100$

A. Intellectual asset generation is relatively weak

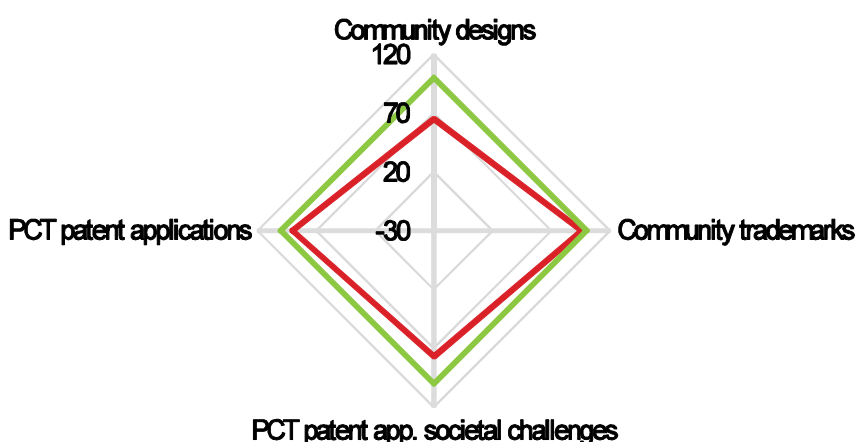

B. Economic effects of innovation

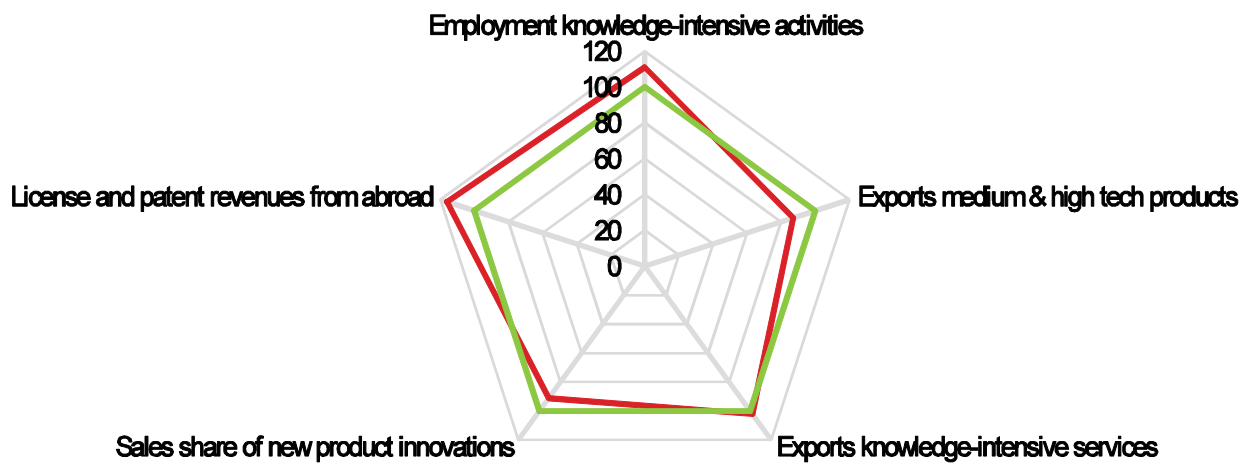

Source: European Commission, European Innovation Scoreboard, 2016.

Belgium also scores relatively poorly in commercialisation of new products ("sales share of new product innovations"). Commercialisation of public research can occur through several channels, including patents, licences, and spin-offs, as well as collaborative research, researcher mobility and contract research (OECD, 2013a). All major research universities and research centres in Belgium have technology transfer offices that act as liaisons between researchers, companies and public authorities. In particular, they are responsible for the protection of intellectual property, the transfer of technologies to private firms and the creation of spin-off companies. However, the evaluation of the competitiveness clusters in the Walloon Region (Iweps, 2014) suggest that many R\&D projects focusing on the commercialisation of their output too late thereby insufficiently implicating potential customers in the process. On the other hand, some Belgian research institutions, such as KU Leuven, rank among the most innovative research outlets in Europe.

Belgium performs well in terms of innovation outcomes. This is particularly the case for product and process innovations, where all three regions score well above the EU average (Figure 9). The BrusselsCapital Region scores relatively poorly in new-to-market innovations, but this outcome can be attributed to its economic structure, which is heavily dominated by services and lacks manufacturing firms. 
Figure 9. Innovation outcomes are generally strong

Relative performance to the EU, 2012

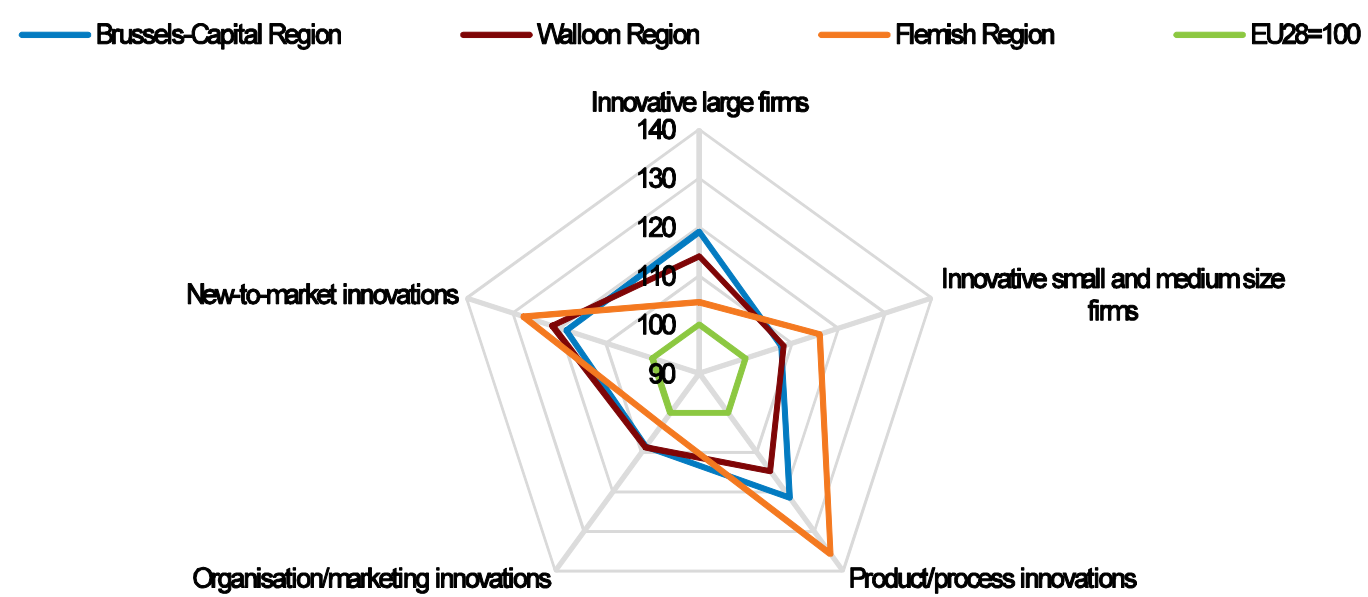

Note: Data for 2012.

Source: innovationdata.be, Scientific and Technical Information Service, Belgian Science Policy Department.

\section{Enhancing technological diffusion throughout the economy}

Strong, broad-based productivity growth requires that technological and organisational advances made by innovators are widely diffused to other firms in the economy. However, while a small share of Belgium firms have productivity levels that are among the highest in Europe, many others are far less productive (Figure 10). While a high dispersion of productivity levels across firms is not unique to Belgium (Verschelde et al., 2014), the difference between the productivity levels of the mean and median firms is unusually large.

Figure 10. The distribution of labour productivity across firms is wide

Real value added per employee averaged, 2007-13

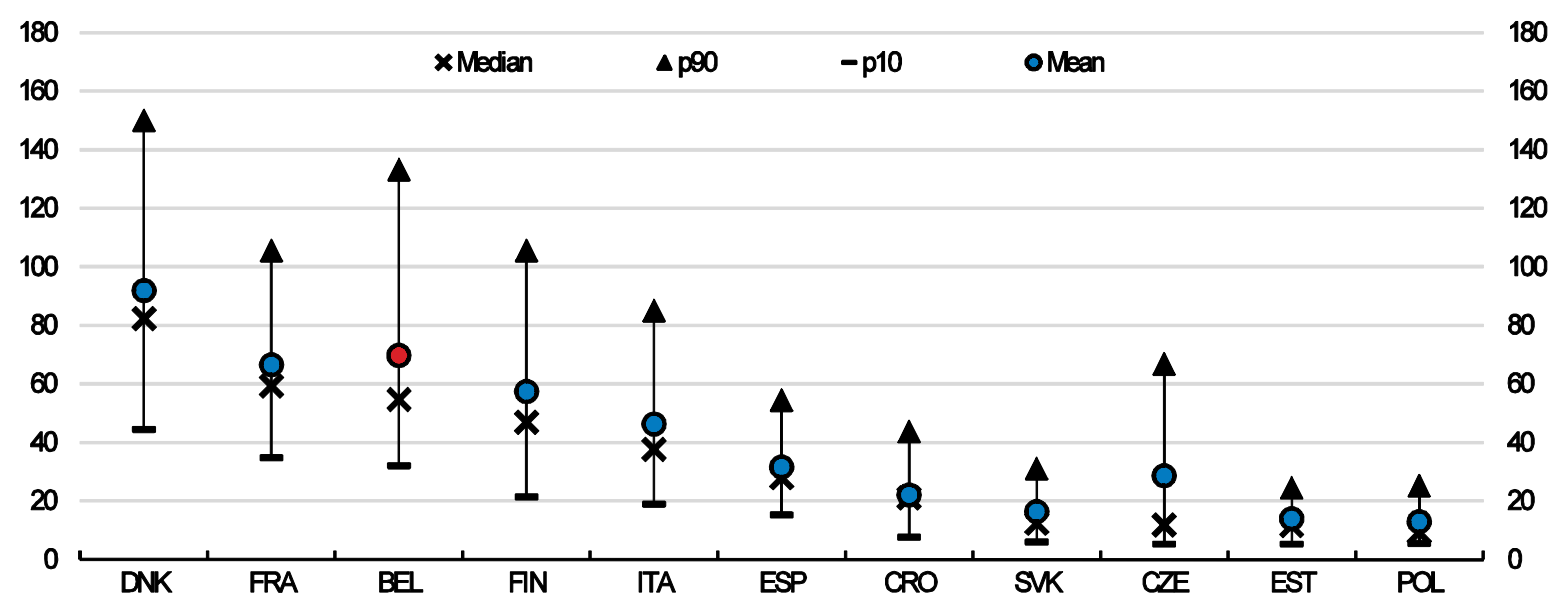


One explanation for the inter-firm diversity in productivity performance is the level of integration in global value chains. Belgium has been very successful in attracting inward foreign direct investment (FDI), with the FDI-to-GDP ratio amounting to $98 \%$ in 2016, compared to an average of $37 \%$ for the OECD. Belgium has a large presence of so-called coordination centres, which finance the international activities of multinational groups. While multinationals represent only $1 \%$ of all firms registered in Belgium, they account for $38 \%$ of the country's value-added and $29 \%$ of private sector employment (Duprez and Van Nieuwenhuyze, 2016), as well as more than 60\% of all R\&D spending (Figure 3). Moreover, innovations at the global frontier tend to be quickly adopted by multinationals and dispersed to their affiliates around the world. Also, survey results indicate that $37 \%$ of all multinationals in Belgium invested in R\&D in 2013, compared with only $8 \%$ of non-exporting firms (NBB, 2016a). Thus, domestic companies that have direct commercial relationships with multinationals can benefit from their innovation through spillover effects. Indeed, recent research shows that the productivity gap to frontier firms increases with the distance to multinationals (OECD, 2015a, NBB, 2016a). A firm that supplies intermediate inputs or services directly to a multinational has a productivity level that is $28 \%$ below the multinational itself, while the gap is $44 \%$ for a company without either direct or indirect exposure to a frontier firm (Table 1).

Table 1. The productivity gap widens with distance to multinationals

(Difference in productivity level with respect to multinational firms)

\begin{tabular}{ll}
\hline \multicolumn{1}{c}{ Firm type } & Gap \\
\hline $1^{\text {st }}$ rank domestic suppliers & $-27.6 \%$ \\
$2^{\text {nd }}$ rank domestic suppliers & $-35.9 \%$ \\
$3^{\text {rd }}$ rank domestic suppliers & $-45.3 \%$ \\
Other domestic firms & $-44.4 \%$ \\
\hline
\end{tabular}

Note: $\mathrm{A} 1^{\text {st }}$ rank domestic supplier is a Belgian firm that supplies intermediate inputs to at least one multinational. $\mathrm{A}$ i-th rank domestic supplier is a Belgian firm that does not supply a multinational, but that supplies (i-1)th rank domestic suppliers

Source: NBB, 2016 a.

As in many other countries, the number of export firms is relatively small. Less than $5 \%$ of enterprises sell their products abroad and almost half of these firms export less than $10 \%$ of their total turnover (Dhyne and Duprez, 2013). However, if indirect exports, i.e. providing inputs for downstream exporters, are taken into account the share of export firms rises to $82 \%$, with about $10 \%$ of firms exporting more than a quarter of their production. In Belgium, a high degree of specialisation and integration into long supply chains with many separate production stages is associated with higher MFP growth of participating firms (Dhyne and Duprez, 2015). The results also indicate that the positive effects on productivity are not evenly distributed along the production chain, with firms closer to the end-consumer generating more value added, as they often have larger pricing power. Belgium's strong export sectors, including chemicals and metals, tend to be in intermediate products rather than consumer goods, so that only a part of total exports benefit from the progressive supply chain effect.

To foster supply chain integration, Belgium maintains an open trade regime and has less stringent regulation than the OECD average in 20 out of 22 sectors according to the OECD's Services Trade Restrictiveness Index (OECD, 2017a). However, in accounting, auditing and architectural services ownership restrictions impede international integration. In companies providing auditing and accounting services, $50 \%+1$ of the voting rights must be owned by locally registered professionals. In companies providing architectural services, $60 \%$ of the voting rights and equities must be owned by locally registered professionals. These rules apply equally to Belgian and foreign nationals. For EU nationals, the rules of recognition of qualifications of directive 2005/36/EG are applicable. The conditions for access of legal persons to economic and intellectual professions such as architects and accountants are currently being reviewed. In addition restrictions on the movement of people (for example, duration of stays are limited to 
6 months for non-EU service suppliers) impede international integration. The authorities should continue to promote trade openness, international connectivity and mobility of highly skilled labour to achieve more pervasive GVC integration of domestic firms.

\section{Continuing infrastructure and regulatory reforms}

Global production chains require strong transport and logistics networks to effectively move goods and people. Belgium ranks sixth out of 160 countries in the World Bank's Logistics Performance Index (WB, 2016b). However, dearth of public investment has meant that the quality of some types of infrastructure, in particular the road and rail networks, is deteriorating and is only slowly adjusting to changing needs. In 2006/07, the World Economic Forum ranked Belgium 10th in the world for the quality of roads, by 2015 it had dropped to 30th (WEF, 2016). The Inrix 2015 traffic scorecard, which is based on real-time monitoring of average speeds and traffic volumes in more than 100 metropolitan areas in the United States and Europe, ranked Belgium as the European country with the worst congestion. Out of the five worst affected urban centres in Europe, two are Belgian (Antwerp and Brussels), with commuters on average spending 70 hours or more in traffic per year. These congestion costs discourage FDI and the inflow of highly qualified professionals. In addition to improving public transport the authorities should prioritise public investment in road infrastructure around the major agglomerations.

Some promising infrastructure investment initiatives have already been initiated. In April 2016 the regions, which have the authority over the road system, introduced a new toll on heavy trucks. The levy is charged for using motorways, as well as a number of regional and municipal roads. The proceeds of the charges are used to finance road maintenance. The authorities might want to explore whether such user fees could also be introduced for other infrastructure services, such as the rail network, to help fund upkeep and avoid further deterioration of the existing infrastructure stock.

In April 2016 the government of the Brussels-Capital Region approved a multi-annual investment plan to renovate the tunnels in the region. The investment plan foresees annual outlays of EUR 50 million to EUR 60 million over a period of 15 years. In March 2017, the Flemish government approved a EUR 3.6 billion investment plan for the period 2017-23 to complete the Oosterweel Junction.

One welcome development in traffic management is the development of a Regional Express Network (Réseau Express Régional/Gewestelijk Expresnet) around Brussels. This mobility solution, which began in December 2015, aims to integrate different modes of public transport, notably trains, subways, trams and buses, to reduce congestion. The approach could be usefully extended to other urban areas.

Belgium invested $2.7 \%$ of its GDP in ICT in 2013, just below the OECD average. According to the EU's Digital Economy and Society sub-index on integration of digital technology, which measures the digitisation of businesses and their exploitation of online sales channel, Belgium ranks fourth among the 28 EU countries (Figure 11). Results from the underlying enterprise survey of 4500 firms show that broadband usage was almost universal in Belgium by 2016, and that more than two-thirds of all companies had an internet presence. However, there is some regional diversity in ICT adoption. In particular, the use of internet and e-commerce facilities was on average somewhat lower in the Walloon Region than in the Flemish Region and the Brussels-Capital Region (Figure 12). 
Figure 11. ICT usage in Belgian firms is comparatively high

EU's Digital Economy and Society sub-index on integration of digital technology, 2016

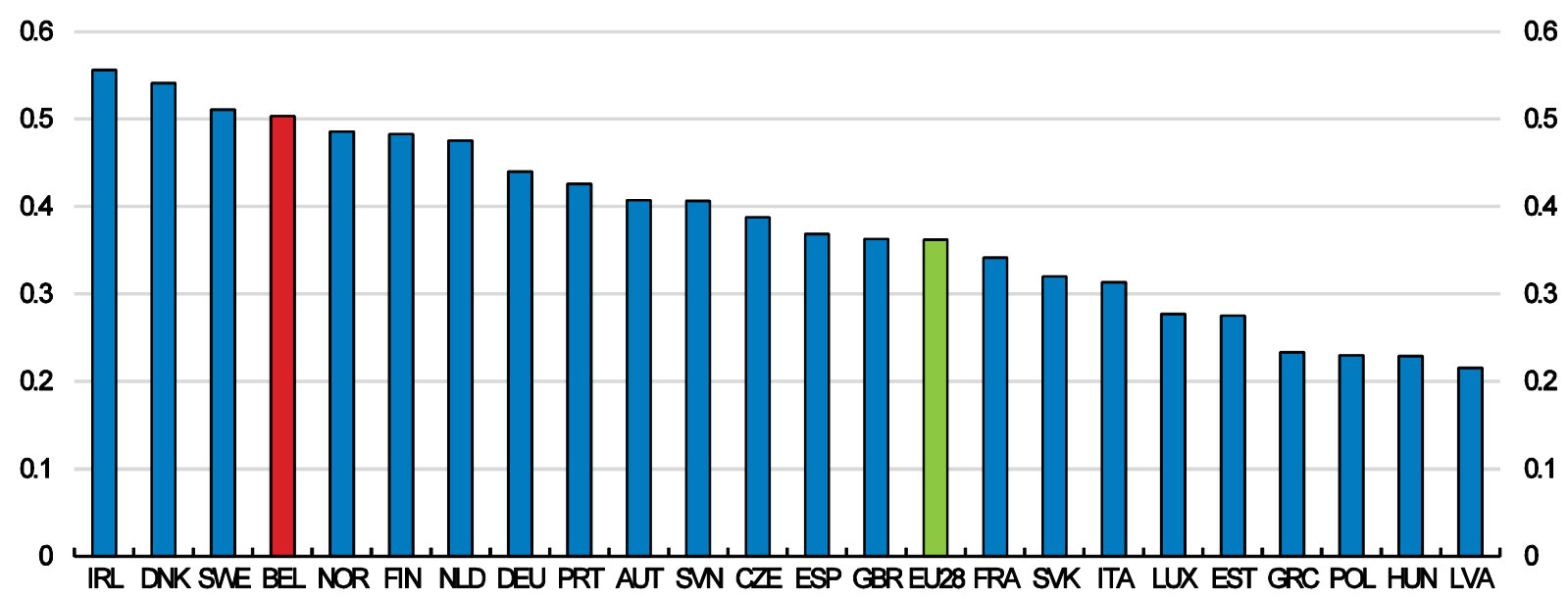

Source: EC, 2017.

Figure 12. ICT adoption by enterprises varies across regions

As a percentage of all enterprises, 2016

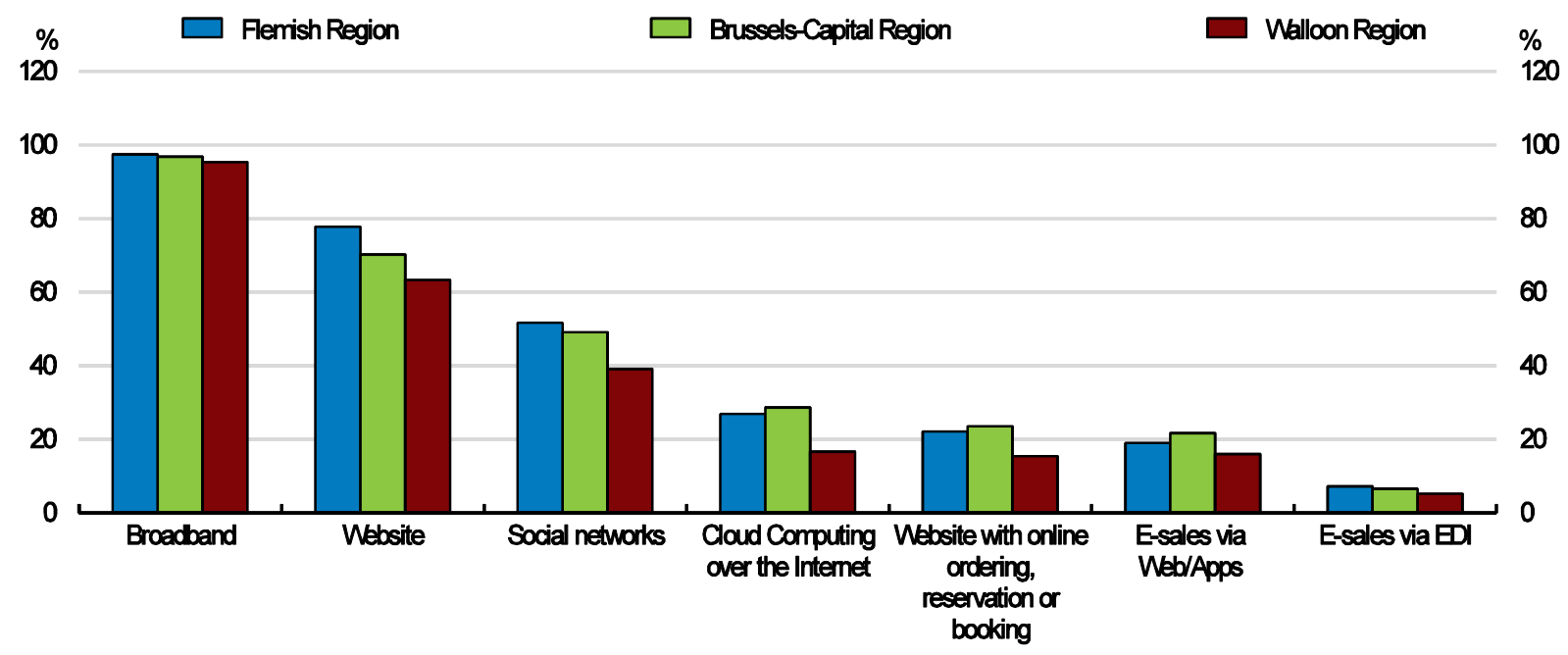

Source: Statistics Belgium.

In April 2015, the Federal government launched a new medium-term action plan "Digital Belgium" to further strengthen ICT usage. It strengthens the digital economy, develops digital infrastructure, fosters digital skills and jobs, enhances digital security and confidence, and facilitates digital government. The plan contains three numerical objectives that are to be achieved by 2020: move into the top 3 in the EU's ranking according to the overall Digital Economy and Society Index (up from $5^{\text {th }}$ place in 2016); create 50000 new jobs in sectors related to the digital economy; and help foster 1000 start-ups.

New models of doing business based on innovative internet platforms, such as ride-sharing or accommodation renting, have developed rapidly in recent years. These new service providers often offer 
cost advantages for consumers and businesses and, thus, make it possible for the economy to be more productive with its existing resources. To take full advantage of the benefits of such market disruption, the policy challenge is to provide an enabling environment that removes any unintended barriers to entry, while ensuring a level playing field between newcomers and traditional service providers in terms of taxation and respect of social values (Figure 13).

Figure 13. Some sectors remain highly regulated

\section{A. OECD PMR Indlcator, lower Is less restrictive}

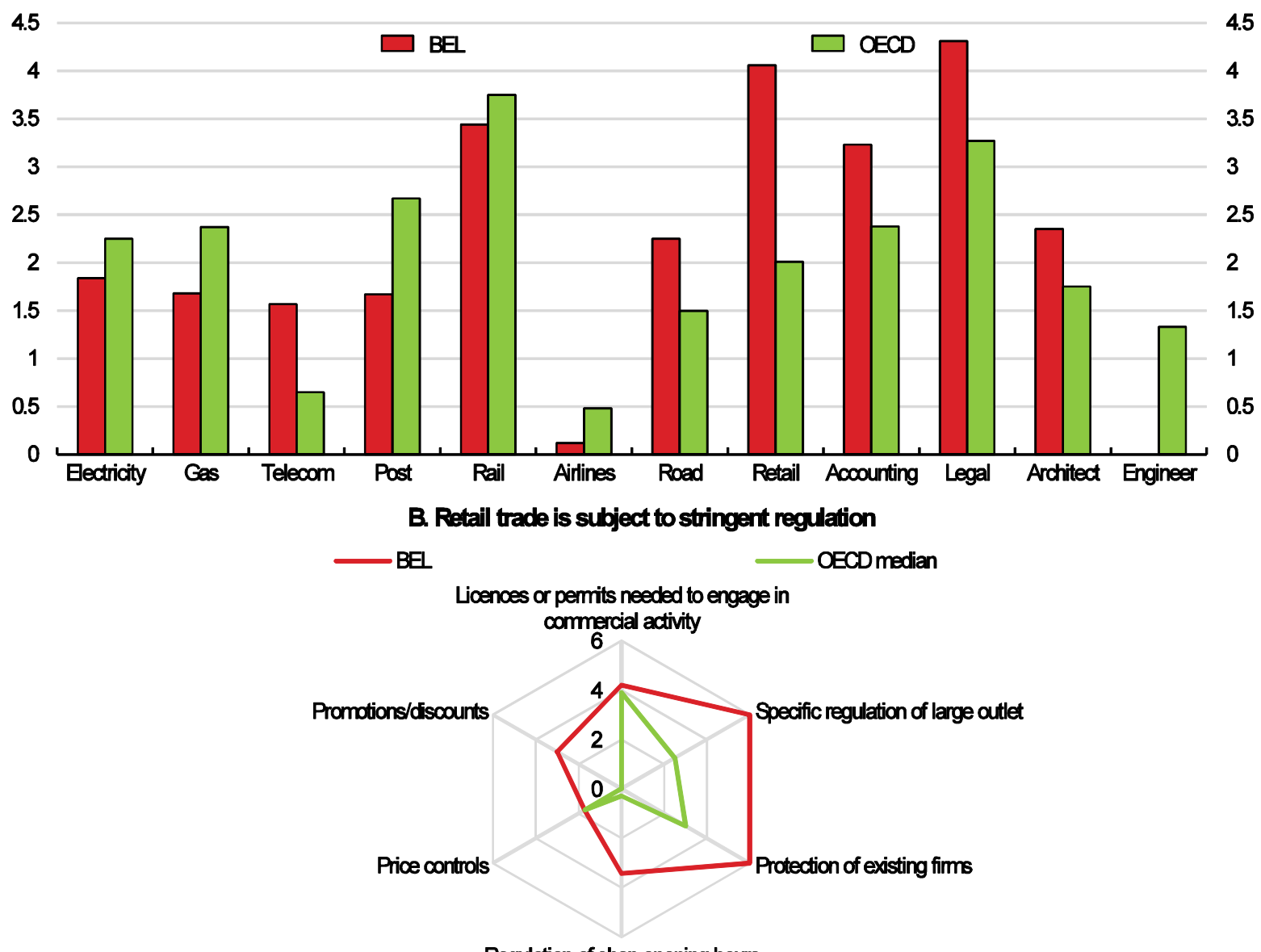

Source: OECD (2013b), Product Market Regulation Database.

In March 2017 Belgium introduced new income tax legislation aimed at ensuring more equal treatment of income obtained through the sharing economy. The law consists of an advantageous (but limited) tax regime for individual service providers who operate through a digital platform and a tax withholding at source by the digital platform. In particular, the effective tax rate on income from the sharing economy that does not exceed EUR 5000 per year is fixed at $10 \%$ and is thus often lower than the personal income tax rate. Tax collection is based on electronic payment records of the digital platform. However, the scope of the new legislation remains limited to services that are provided between nonprofessional individuals, and excludes goods (e.g. takeaways) as well as the letting of real property (e.g. AirBnB) or movables (e.g. car-sharing). With such important parts of the sharing economy excluded, there is a risk that income from platform activities is not fully reported and distortions vis-à-vis traditional service providers persevere. In this context, the authorities should aim to broaden the coverage of the legislation to other activities within the sharing economy. 


\section{Policy recommendations on improving the business environment}

\section{Key recommendations}

- $\quad$ Further streamline public support for R\&D and innovation within each Region. Regions and Communities could step up their innovation support cooperation where appropriate.

- $\quad$ Further reduce administrative burdens on SMEs stemming from federal and regional measures; reduce the level of paid-in minimum capital requirements and strengthen contract enforcement by strengthening court automation and case management. Ensure appropriate financing tools are available for scaling up of young, innovative firms.

\section{Other recommendations}

\section{Research and Innovation}

- Critically assess the effectiveness of the tax credit/investment deduction for R\&D program, with a view to improving the existing programmes.

- Continue to strengthen entrepreneurship education, promote identifiable role models and champions, and expand existing mentor and patron panels of retired business people to counsel new company founders.

Access to finance for start-up

- Improve the effectiveness of existing tax incentives for retail investors based SME funding by a more neutral tax treatment of income from savings deposits. Encourage simple transparent and standard securitisation of SME loans by banks. Improve coordination between public sector entities responsible for SME financing.

\section{Infrastructures}

- $\quad$ Explore whether user fees could be introduced for a broader range of infrastructure services to fund upkeep and avoid a further deterioration of the existing infrastructure stock.

- $\quad$ Articulate a clear medium to long-term strategy for energy production to reduce policy uncertainty and thus facilitate long-life-cycle investments. 


\section{REFERENCES}

Ahmad, N. and P. Schreyer (2016), "Measuring GDP in a Digitalised Economy", OECD Statistics Working Papers, No. 2016/07, OECD Publishing, Paris, http://dx.doi.org/10.1787/5jlwqd81d09r-en.

Andrews, D., C. Criscuolo and P. Gal (2015), "Frontier Firms, Technology Diffusion and Public Policy: Micro Evidence from OECD Countries", OECD Productivity Working Papers, No. 2, OECD Publishing, Paris, http:// dx.doi.org/10.1787/5jrql2q2jj7b-en.

Appelt, S., M. Bajgar, C. Criscuolo and F. Galindo-Rueda (2016), "R\&D Tax Incentives: Evidence on design, incidence and impacts", OECD Science, Technology and Industry Policy Papers, No. 32, OECD Publishing, Paris, http://dx.doi.org/10.1787/5jlr8fldqk7j-en.

Ariu, A. and V. Vandenberghe (2014), "Assessing the role of ageing, feminising and better-educated workforces on TFP growth", NBB Working Paper, No. 265, National Bank of Belgium, Brussels.

Baumol, W.J. (2002), The Free-Market Innovation Machine: Analyzing the Growth Miracle of Capitalism, Princeton University Press.

Bergmann, H. (2007), "Cultural Aspects of Entrepreneurship", in OECD, Key Issues in Entrepreneurship and SME Development, OECD Publishing, Paris.

Biatour, B., J. Fiers, C. Kegels and B. Michel (2007), "Growth and Productivity in Belgium", Federal Planning Bureau, Working Paper 5-07, Brussels.

Biatour, B. and C. Kegels (2008), "Growth and Productivity in Belgium", Federal Planning Bureau, Working Paper 17-08, Brussels.

Boulhol, H. and L. Turner (2009), "Employment-Productivity Trade-off and Labour Composition”, OECD Economics Department Working Papers, No. 698, OECD Publishing, Paris, http://dx.doi.org/10.1787/ 224146182015.

Calvino, F., C. Criscuolo and C. Menon (2016), "No Country for Young Firms?: Start-up Dynamics and National Policies", OECD Science, Technology and Industry Policy Papers, No. 29, OECD Publishing, Paris, http://dx.doi.org/10.1787/5jm22p40c8mw-en.

CompNet (2016), Competitiveness Research Network database.

Conference Board (2017), Total Economy Database, www.conferenceboard.org/data/economydatabase/index. $c f m ? i d=27762$.

CREG-PwC (2016), A European comparison of electricity and gas prices for large industrial consumers, Brussels.

De Mulder, J. and H. Godefroid (2016), “Comment stimuler l'entrepreneuriat en Belgique ?", NBB Economic Review, September 2016.

Dervis, K. and Z. Qureshi (2016), The productivity slump - fact of fiction: The measurement debate, Brookings Institution, Washington, DC. 
Dhyne, E. and C. Duprez (2013), "Structural dynamics of Belgium's foreign trade", NBB Economic Review, June 2013.

Dhyne, E. and C. Duprez (2015), "Has the crisis altered the Belgian economy's DNA?", NBB Economic Review, September 2015.

Dumont, M. and C. Kegels (2016), "Young Firms and Industry Dynamics in Belgium", Federal Planning Bureau, Working Paper 6-16, Brussels.

Duprez, C. and C. Van Nieuwenhuyze (2016), "Inward and Outward Foreign Direct Investment in Belgium", NBB Economic Review, September 2016, pp. 45-62.

EC (2016a), RIO Country Report 2015: Belgium, JRC Science for Policy Report, European Commission.

EC (2016b), European Innovation Scoreboard 2016, European Commission.

EC (2017), The Digital Economy and Society Index (DESI), https://ec.europa.eu/digital-singlemarket/en/desi.

ECB (2015), Survey on the Access to Finance of Enterprises (SAFE) 2015, European Central Bank.

ECB (2016), Survey on the Access to Finance of Enterprises (SAFE) 2016, European Central Bank.

HLEG (2016), The Future of the Belgian Financial Sector, Report of the High Level Expert Group established on the initiative of the Minister of Finance of Belgium.

IMF (2016), Acting Now - Acting Together, Fiscal Monitor, April, International Monetary Fund, Washington DC.

Iweps (2014), Evaluation du Plan Marshall 2.Vert; Evaluation thématique $n^{\circ} 1$; Pôles de compétitivité; Rapport final; Belgrade/Belgium.

Kalenga-Mpala, R. and A. Wautelet (2016), "La recherche et le développement à Bruxelles : qui finance ces activités et où sont-elles réalisées ?", Focus, 12, January 2016.

Kegels, C. and Van der Linden (2011), “Competitiveness, productivity competition and structural reforms': The Belgian case", Reflets et perspectives de la Vie Économique.

Nassr, I.K. and G. Wehinger (2015), "Unlocking SME finance through market-based debt: Securitisation, private placements and bonds", OECD Journal: Financial Market Trends, Vol.2014/2, http://dx.doi.org/ 10.1787/fmt-2014-5js3bglg53ln.

Nassr, I.K. and G. Wehinger (2016), "Opportunities and Limitations of Public Equity Markets for SMEs", OECD Journal: Financial Market Trends, http://dx.doi.org/10.1787/fmt-2015-5jrs051funjk.

NBB (2016a), Annual Report 2015, National Bank of Belgium.

NBB (2016b), "Raising the growth potential and resilience of the economy", in Annual Report, National Bank of Belgium.

OECD (2013a), OECD Science, Technology and Industry Scoreboard 2013: Innovation for Growth, OECD Publishing, Paris, http://dx.doi.org/10.1787/sti_scoreboard-2013-en. 
OECD (2013b), PMR indicators Database, www.oecd.org/eco/growth/indicatorsofproductmarketregulationhomepage.htm.

OECD (2014), Countering Harmful Tax Practices More Effectively, Taking into Account Transparency and Substance, Action 5 - 2015 Final Report, OECD Publishing, Paris, http://dx.doi.org/10.1787/9789264241190-en.

OECD (2015a), The Future of Productivity, OECD Publishing, Paris, http://dx.doi.org/10.1787/9789264248533-en.

OECD (2015b), OECD Economic Surveys: Belgium 2015, OECD Publishing, Paris.

OECD (2015c), Opportunities and Constraints of Market-Based Financing for SMEs, OECD's Report to G20 Finance Ministers and Central Bank Governors, September 2015, available at www.oecd.org/g20/ meetings/antalya/Opportunities-and-Constraints-of-Market-based-Financingfor-SMEs.pdf.

OECD (2015d), Entrepreneurship at a Glance 2015, OECD Publishing, Paris. http://dx.doi.org/10.1787/entrepreneur_aag-2015-en

OECD (2016a), OECD Science, Technology and Innovation Outlook 2016, OECD Publishing, Paris, http:// dx.doi.org/10.1787/sti_in_outlook-2016-en.

OECD (2016b), Financing SMEs and Entrepreneurs 2016: An OECD Scoreboard, OECD Publishing, Paris, http:// dx.doi.org/10.1787/fin_sme_ent-2016-en.

OECD (2016c), OECD Productivity Statistics Database, www.oecd.org/std/productivity-stats.

OECD (2016d), Entrepreneurship at a Glance 2016, OECD Publishing, Paris. http://dx.doi.org/10.1787/entrepreneur_aag-2016-en

OECD (2017a), OECD Services Trade Restrictiveness Index (STRI): Belgium, www.oecd.org/tad/servicestrade/ STRI_BEL.pdf.

OECD (2017b), Main Science and Technology Indicators, www.oecd.org/sti/msti.htm.

Piette, C. and M.D. Zachary (2015), "Sensitivity to the crisis of SME financing in Belgium", National Bank of Belgium Working Paper.

Soete, L. (2012), Expertgroep voor de doorlichting van het Vlaams innovatieinstrumentarium.

SPF Economie (2015), Financement des PME 2014, SPF Economie, P.M.E., Classes moyennes et Energie - Observatoire des PME, Brussels.

Statistics Belgium (2017), https://bestat.economie.fgov.be/bestat/.

Straathof, B., E. Gaillard Ladinska, H.L.M. Kox and R. Mocking (2014), "A study on R\&D tax incentives: Final Report", EU Taxation Paper No. 52 (2014).

Syverson, C. (2016), "Challenges to Mismeasurement Explanations for the U.S. Productivity Slowdown", NBER Working Paper Series, Working Paper 21974, Cambridge, MA: National Bureau of Economic Research. 
Van Beveren, I. and S. Vanormelingen (2014), "Human capital, firm capabilities and productivity growth", NBB Working Paper No. 257, National Bank of Belgium, Brussels.

Verschelde, M., M. Dumont, G. Rayp and B. Merlevede (2014), "European Competitiveness: A semiparametric stochastic meta-frontier analysis at the firm level", European Central Bank, Working Paper No. 1701, Frankfurt.

WB (2016a), Doing Business 2017: Equal Opportunity for All, Washington DC.

WB (2016b), Logistics Performance Index 2016, http://lpi.worldbank.org/international/global.

WEF (2016), Global Competitiveness Report, Geneva.

Wilson, K. and F. Silva (2013), "Policies for Seed and Early Stage Finance: Findings from the 2012 OECD Financing Questionnaire", OECD Science, Technology and Industry Policy Papers, No. 9, OECD Publishing, Paris, http://dx.doi.org/10.1787/5k3xqsf00j33-en. 